American Journal of Applied Sciences 9 (7): 1030-1036, 2012

ISSN 1546-9239

(C) 2012 Science Publications

\title{
An Investigation of Compressed Natural Gas Engine for Nitrogen Oxides Reduction
}

\author{
${ }^{1}$ Diaz, P.M. and ${ }^{2}$ B. Durga Prasad \\ ${ }^{1}$ Department of Mechanical Engineering, Sathyabama University, India \\ ${ }^{2}$ Department of Mechanical Engineering, \\ JNTU College of Engineering, Ananthapur (AP), India
}

\begin{abstract}
Problem statement: This study describes the use of Reformer Gas (RG) to alter $\mathrm{NO}_{\mathrm{x}}$ emission in a CNG-fueled HCCI engine. Comparison with diesel, natural gas has a very high octane number $(\approx 120)$ and high auto-ignition temperature $\left(\approx 600^{\circ} \mathrm{C}\right)$. Composed mostly of methane, natural gas is the only common fuel to manifest relatively pure, single-stage combustion. Other fuels have stronger low-temperature reaction and the required entropy for main stage combustion can be obtained from the low temperature heat release as a result of compression to moderate pressure and temperature. In deviation, the methane molecule resists destruction by free radicals and produces negligible heat release at low temperature. In consequences, in CNG-fueled HCCI engines the activation energy required for auto-ignition must be obtained by extreme levels of charge heating and compression. This causes inherently to a high rate of heat release. HCCI operation with pure CNG fuel was attained but not really practical due to very high $\mathrm{NO}_{\mathrm{x}}$ production. While HCCI operation is usually described as a low $\mathrm{NO}_{\mathrm{x}}$ technique, the knocking behavior when running with pure $\mathrm{CNG}$ raised the peak combustion temperature to a value well above normal combustion and the critical Zeldovich $\mathrm{NO}_{\mathrm{x}}$ production threshold, giving very high indicated $\mathrm{NO}_{\mathrm{x}}$ emissions. Approach: One approach to improving these properties is to convert part of the base CNG fuel to Reformer Gas (RG). In this study, modified COMET engine was operated in HCCI mode using a mixture of $\mathrm{CNG}$ fuel and simulated $\mathrm{RG}\left(75 \% \mathrm{H}_{2}\right.$ and $\left.25 \% \mathrm{CO}\right)$ can be produced on-board from $\mathrm{CNG}$ using low current and non-thermal plasma boosted fuel converter. Results: This study shows that despite of having various RG mass fractions, $\lambda$ was the dominant factor in reducing $\mathrm{NO}_{\mathrm{x}}$ production and increasing RG mass fraction had only a small effect on increasing $\mathrm{NO}_{\mathrm{x}}$. This disconnect between the overall equivalence ratio and $\mathrm{RG}$ fraction shows that the real benefit of the RG blending was to enable lean (high) operation. Higher $\lambda$ also effectively reduced maximum pressure and maximum pressure rate. Conclusion: Note that due to the low achievable power levels, the $\mathrm{NO}_{\mathrm{x}}$ emissions continue to be high and further combustion enhancements and more controlled combustion would be needed to make the CNG-fuelled HCCI engine practical.
\end{abstract}

Key words: Homogeneous charge compression ignition, compressed natural gas, reformer gas, air/fuel ratio, overall equivalence, $\mathrm{RG}$ mass, $\mathrm{RG}$ fraction, HCCI mode, COMET engine, $\mathrm{NO}_{\mathrm{x}}$ production

\section{INTRODUCTION}

The internal combustion engine the vital to the current society. Without the transportation performed by the millions of vehicles on the road and at sea we would not have achieved the living standard of modern life. We have two types of internal combustion engines such as spark ignition engine and compression ignition engine. Both have their merits. The SI engine is a preferably simple product and hence has a lower first cost. This engine type in addition made very clean as the Three-Way Catalyst (TWC) is effective for exhaust after treatment. The problem with the a park ignition engine is the poor part load efficiency due to large losses during gas exchange and low combustion and thermo dynamical efficiency. The compression ignition engine is much more fuel efficient and hence the existing choice in applications where fuel cost is more important than initial cost. The problem with the CI engine is the emissions of nitrogen oxides and particulate matter. The treatment to reduce nitrogen oxides and PM is costly and still not generally available on the market. The natural choice of ideal combination would be to find an engine type with the high efficiency

Corresponding Author: Diaz, P.M., Department of Mechanical Engineering, Sathyabama University, India 
of the CI engine and the very low emissions of the spark ignition engine engine with three-way catalyst. One such new concept is named Homogeneous Charge Compression Ignition (HCCI). Homogeneous Charge Compression Ignition engine is a new concept for future power trains which will provide improved fuel efficiency and lower emissions at the same time. It is based on the concept of compression ignition of fuel-air mixtures due to reaching auto ignition temperature. However, there are two critical problems associated with the HCCI engines: control of the autoignition timing and the combustion rate. There are a number of strategies that have been currently investigated to address the above two critical problems, such as a variable compression ratio (Haraldsson et al., 2002; Sjoberg and Dec, 2003; Diaz and Prasad, 2010; AlKhairi et al., 2011; Risberg et al., 2006) variable valve timing (Kaahaaina et al., 2001) variable intake charge temperature or hot exhaust gas recirculation study (Christensen et al., 1999). The exhaust gas injection in the intake port changes the intake temperature thereby giving a good control on the combustion phasing inside the HCCI engine. However, EGR consist of many gases such as oxides of carbon monoxide, carbon dioxide, nitrogen unburned hydrocarbon and oxides of nitrogen $\left(\mathrm{NO}_{2}, \mathrm{NO}\right)$. Recent studies have indicated that nitric oxide can have an important effect on the kinetics of the autoignition of $\mathrm{HC}$ inside $\mathrm{HCCI}$ engines through NOpromoted production of $\mathrm{OH}$ radical, $\mathrm{HO}_{2}+\mathrm{NO}=$ $\mathrm{OH}+\mathrm{NO}_{2}$ (Kalateh and Ghazikhani, 2012) The presence of $\mathrm{NO}$ in the recirculated exhaust gases in $\mathrm{HCCI}$ engines is now perceived as a potentially a promising concept for controlling the combustion phasing inside these engines. To achieve this, a clear understanding of the in-cylinder nitrogen oxide formation inside the HCCI engine is immediately required, which depends on the in-cylinder combustion characteristics. Experimental quantification of the in cylinder nitrogen oxide formation is time consuming and technically challenging.

\section{MATERIALS AND METHODS}

The Reformer Gas is a mixture of light gases dominated by Hydrogen and Carbon Monoxide and can be produced from Compressed Natural Gas using low current and non-thermal plasma boosted fuel converter. In the COMET engine, HCCI operation on pure Compressed Natural Gas fuel was achieved but not really practical due to very high Nitrogen Oxide production. While HCCI operation is generally characterized as a low Nitrogen Oxides technique, the marginal knocking behavior when running with pure Compressed Natural Gas raised the peak cylinder temperature to a value well above the critical Zeldovich Nitrogen Oxides production mechanism threshold, giving very high indicated Nitrogen Oxides emissions. HCCI operation with leaner mixtures, enabled by Reformer Gas blending, significantly reduced $\mathrm{NO}_{\mathrm{x}}$ production. The formation of Nitrogen Monoxide and Nitrogen Dioxide can be divided into thermal route, prompt route, $\mathrm{N}_{2} \mathrm{O}$ route and fuel-bound nitrogen route (Warnatz et al., 2006). The major $\mathrm{NO}_{\mathrm{x}}$ formation route in IC engine combustion is the thermal route (Heywood, 1988). The thermal NO route is the major constituent to the NOx emission and can be described with the following three elementary reactions called as extended Zeldovich mechanism Eq. 1-3:

$\mathrm{O}+\mathrm{N}_{2} \rightarrow \mathrm{NO}+\mathrm{N}$

$\mathrm{N}+\mathrm{O}_{2} \rightarrow \mathrm{NO}+\mathrm{O}$

$\mathrm{N}+\mathrm{OH} \rightarrow \mathrm{NO}+\mathrm{H}$

Reaction 1 has very high activation energy and is the rate limiting step. The triple bond of the Nitrogen molecule is strong, the consequence of this causes the reaction rate is slow unless the temperature is high. When assuming quasi-steady state for $\mathrm{N}$ concentration, the rate of NO production may be described as Eq. 4:

$\frac{\mathrm{d}[\mathrm{NO}]}{\mathrm{dt}}=2 \mathrm{k}_{1}[\mathrm{O}]\left[\mathrm{N}_{2}\right]$

The $\mathrm{NO}_{\mathrm{x}}$ production may thus be reduced by reducing the concentration of Oxygen or Nitrogen, or reducing the rate coefficient $\mathrm{k}_{1}$ by reducing the temperature. The rate coefficient $\mathrm{k}_{1}$ is considered insignificant at temperatures less than $1700 \mathrm{k}$ (Warnatz et al., 2006).

A common European standard for emission legislations were introduced in 1992 with the EURO 1 standard. Since then, the EURO 2, 3 and 4 has been put into force of implementation with ever more stringent requirements (Warnatz et al., 2006). Table 1 shows the Emission standards for heavy duty diesel and gas engines for the Transient Test Cycle (Heywood, 1988).

In the COMET engine, HCCI operation on pure Compressed Natural Gas fuel was achieved but not really practical due to very high Nitrogen Oxide production.

Experimental setup: All experiments were conducted on a modified COMET engine to operate in HCCI mode using CNG fuel. Table 2 summarizes the engine specifications for the current experiment. The Schematic diagram of Experimental setup is as shown in Fig. 1. 


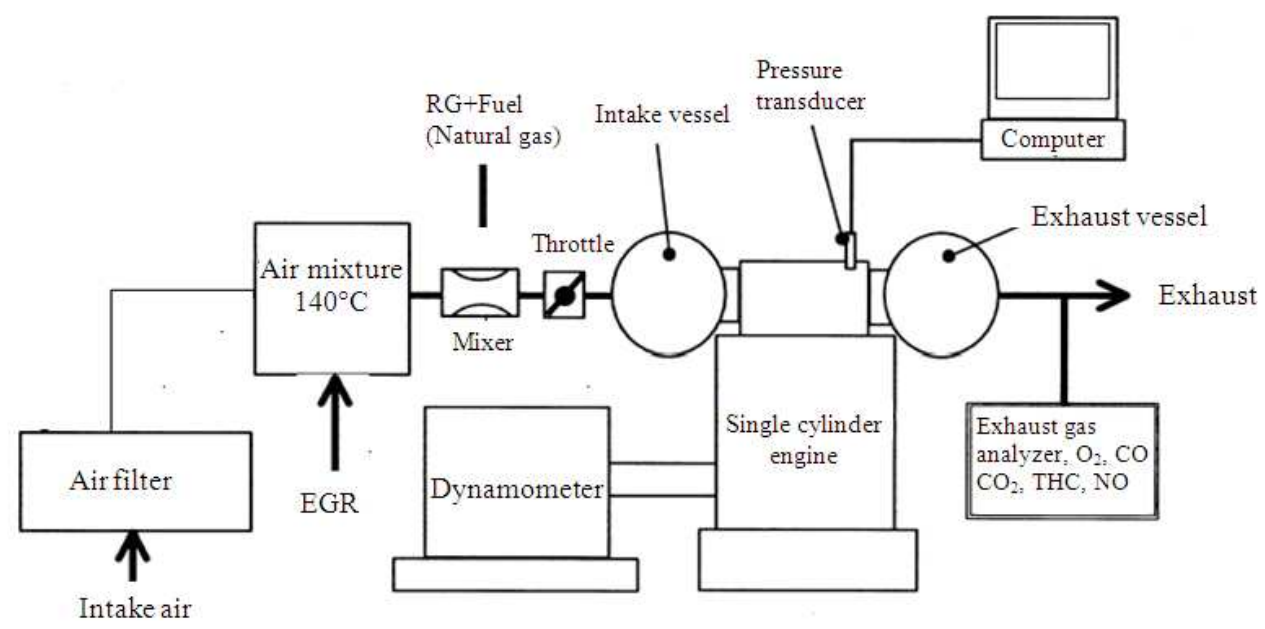

Fig. 1: Schematic diagram of Experimental setup (Satoshi S, SAE, 2001-01-1034)

Table 1: Emission standards for heavy duty diesel and gas engines (motor vehicles over $3500 \mathrm{~kg}$ as maximum laden mass) for the transient test cycle (Heywood, 1988)

Emission standards for diesel and gas engines, ETC test, $\mathrm{g} / \mathrm{kWh}$

\begin{tabular}{|c|c|c|c|c|c|c|c|}
\hline Tier & Date & Test & $\mathrm{CO}$ & NMHC & $\mathrm{CH}_{4}{ }^{\mathrm{a}}$ & $\mathrm{NO}_{\mathrm{x}}$ & $\mathrm{PM}$ \\
\hline \multirow[t]{2}{*}{ Euro III } & 1999.10 EEVs only & ETC & 3.00 & 0.40 & 0.65 & 2.0 & 0.02 \\
\hline & 2000.10 & ETC & 5.45 & 0.78 & 1.60 & 5.0 & $\begin{array}{l}0.16 \\
0.21\end{array}$ \\
\hline Euro IV & 2005.10 & & 4.00 & 0.55 & 1.10 & 3.5 & 0.03 \\
\hline Euro V & 2008.10 & & 4.00 & 0.55 & 1.10 & 2.0 & 0.03 \\
\hline
\end{tabular}

A: For natural gas engines only, B: Not applicable for gas fueled engines at the year 2000 and 2005 stages, C: For engines of less than $0.75 \mathrm{dm}^{3}$ swept volume per cylinder and a rated power speed of more than $3000 \mathrm{~min}^{-1}$ (Heywood, 1988)

Table 2: Experimental apparatus and fuels

\begin{tabular}{ll}
\hline Engine make & Comet \\
\hline Engine type & Four stroke single cylinder engine \\
Rated power output & $3.5 \mathrm{~kW}$ at a speed of $1500 \mathrm{rpm}$ \\
Bore diameter & $30 \mathrm{~mm}$ \\
Stroke length & $110 \mathrm{~mm}$ \\
Throttle & Fully open \\
Main fuel & CNG \\
Additive fuel & RG \\
CR & 17 \\
\hline
\end{tabular}

\section{RESULTS}

Table 3-7 shows the results obtained from experiments for different operating conditions.

\section{DISCUSSION}

Effect of mixture strength: $\lambda$ : As mentioned already, $\lambda$ represents the total air/fuel ratio considering both the $\mathrm{CNG}$ and $\mathrm{RG}$ as a combined fuel.

In HCCI combustion, the total chemical energy inside the cylinder plays the major role.

Figure 2 indicates that despite of having various RG mass fractions, $\lambda$ was the dominant factor in reducing $\mathrm{NO}_{\mathrm{x}}$ production and increasing $\mathrm{RG}$ mass fraction had only a small effect on increasing $\mathrm{NO}_{\mathrm{x}}$.

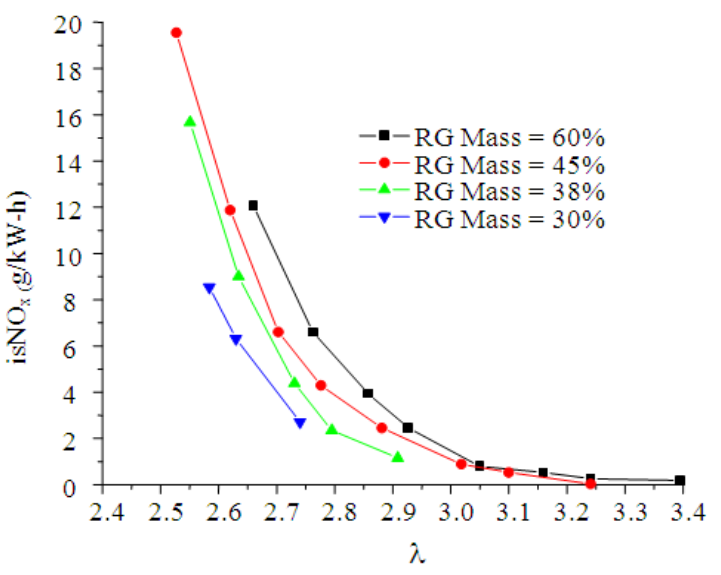

Fig. 2: Effect of relative air fuel ratio on is $\mathrm{NO}_{\mathrm{x}}$ at constant RG mass fraction lines.

Figure 2 shows that the governing factor to decrease $\mathrm{NO}_{\mathrm{x}}$ is $\lambda$, especially when looking at $\lambda$ greater than 2.9. This disconnect between the overall equivalence ratio and RG fraction shows that the real benefit of the RG blending was to enable lean (high $\lambda$ ) operation, (which is similar to the benefits seen for hydrogen and RG blending for non-HCCI engines). 
Am. J. Applied Sci., 9 (7): 1030-1036, 2012

Table 3: Effect of Relative air fuel ratio on is $\mathrm{NO}_{\mathrm{x}}$ at constant $\mathrm{RG}$ mass fraction

\begin{tabular}{lllll}
\hline $\begin{array}{l}\text { Relative air } \\
\text { fuel ratio, } \lambda\end{array}$ & $\begin{array}{l}\text { Is } \mathrm{NO}_{\mathrm{x}} \text { Emission } \\
\text { at } \mathrm{RG}=60 \%,\end{array}$ & $\begin{array}{l}\text { is } \mathrm{NO}_{\mathrm{x}} \text { Emission at } \\
\mathrm{RG}=45 \%,\end{array}$ & $\begin{array}{l}\text { is } \mathrm{NO}_{\mathrm{x}} \text { Emission at } \\
\mathrm{RG}=38 \%,\end{array}$ & $\begin{array}{l}\text { is } \mathrm{NO}_{\mathrm{x}} \text { Emission } \\
\text { at } \mathrm{RG}=30 \%, \\
\text { in }(\mathrm{kg} / \mathrm{kW}-\mathrm{h})\end{array}$ \\
\hline 2.76221 & in $(\mathrm{kg} / \mathrm{kW}-\mathrm{h})$ & in $(\mathrm{kg} / \mathrm{kW}-\mathrm{h})$ & 6.316180 \\
2.85822 & 6.60716 & 11.871220 & 9.003120 & 2.716711 \\
2.92627 & 3.93113 & 6.601210 & 4.382150 & 2.301140 \\
3.0418 & 2.45150 & 4.291410 & 2.351400 & 1.101820 \\
3.1519 & 0.80109 & 2.415200 & 1.158120 & 0.790160 \\
3.24018 & 0.53132 & 0.891060 & 0.800160 & 0.427180 \\
3.39514 & 0.21630 & 0.521780 & 0.501780 & 0.025516 \\
\hline
\end{tabular}

Table 4: Effect of relative air-fuel ratio of maximum pressure and maximum pressure rate at constant RG mass fractions

\begin{tabular}{|c|c|c|c|c|}
\hline & & $\left(\frac{\mathrm{dp}}{\mathrm{d} \theta}\right)_{\max }$ & & $\left(\frac{\mathrm{dp}}{\mathrm{d} \theta}\right)_{\max }$ \\
\hline $\begin{array}{l}\text { Relative air } \\
\text { fuel ratio, } \lambda\end{array}$ & $\begin{array}{l}P_{\max } \text { at } R G=45 \% \\
\text { In bar }\end{array}$ & $\begin{array}{l}\text { at } \mathrm{RG}=45 \% \\
\text { In bar }\end{array}$ & $\begin{array}{l}P_{\max } \text { at } R G=30 \% \\
\text { In bar }\end{array}$ & $\begin{array}{l}\text { at } R G=30 \% \\
\text { In bar }\end{array}$ \\
\hline 2.76211 & 77.72815 & 77.952230 & 76.91253 & 75.42233 \\
\hline 2.85182 & 77.52110 & 77.298180 & 73.97526 & 73.01128 \\
\hline 2.92267 & 77.53713 & 75.531730 & 67.40224 & 69.32167 \\
\hline 3.04298 & 73.11115 & 73.101990 & & \\
\hline 3.1529 & 70.69422 & 71.501820 & & \\
\hline 3.24108 & 68.56329 & 70.042254 & & \\
\hline 3.39514 & 65.85129 & 68.662740 & & \\
\hline
\end{tabular}

Table 5: is $\mathrm{NO}_{\mathrm{x}}$ increase with an increasing RG mass fraction of constant relative air fuel ratio

\begin{tabular}{|c|c|c|c|c|c|c|c|}
\hline $\begin{array}{l}\text { RG\% } \\
\lambda=2.5\end{array}$ & $\begin{array}{l}\text { Is } \mathrm{NO}_{\mathrm{x}} \text { Emission } \\
\text { at } \lambda=2.5 \\
\text { in }(\mathrm{kg} / \mathrm{kW}-\mathrm{h})\end{array}$ & $\begin{array}{l}\mathrm{RG} \% \text { at } \\
\text { at } \lambda=2.6\end{array}$ & $\begin{array}{l}\text { is } \mathrm{NO}_{\mathrm{x}} \text { Emission } \\
\lambda=2.6 \\
\text { in }(\mathrm{kg} / \mathrm{kW}-\mathrm{h})\end{array}$ & $\begin{array}{l}\text { RG\% } \\
\text { at } \lambda=2.7\end{array}$ & $\begin{array}{l}\text { is } \mathrm{NO}_{\mathrm{x}} \text { Emission } \\
\text { at } \lambda=2.7 \\
\text { in }(\mathrm{kg} / \mathrm{kW}-\mathrm{h})\end{array}$ & $\begin{array}{l}\mathrm{RG} \% \text { at } \\
\lambda=2.8\end{array}$ & $\begin{array}{l}\text { is } \mathrm{NO}_{\mathrm{x}} \text { Emission } \\
\text { at } \lambda=2.8 \\
\text { in }(\mathrm{kg} / \mathrm{kW}-\mathrm{h})\end{array}$ \\
\hline$\overline{16}$ & 7.6887 & 30 & 8.58019 & 30 & 2.9425 & 37 & 2.63320 \\
\hline 23 & 11.8026 & 38 & 9.11722 & 38 & 4.57148 & 42 & 2.62280 \\
\hline 30 & 16.15721 & 41 & 10.38528 & 46 & 4.44144 & 46 & 2.62180 \\
\hline 39 & 15.6622 & 45 & 11.95628 & 53 & 6.00837 & 53 & 3.28114 \\
\hline 46 & 19.53233 & 52 & 13.40229 & 59 & 12.06137 & 60 & 4000000 \\
\hline
\end{tabular}

Table 6: Effect of RG on maximum pressure rate at constant relative air fuel ratio

\begin{tabular}{|c|c|c|c|c|c|c|c|}
\hline & $\left(\frac{\mathrm{dp}}{\mathrm{d} \theta}\right)_{\max }$ & & $\left(\frac{d p}{d \theta}\right)_{\text {max }}$ & & $\left(\frac{\mathrm{dp}}{\mathrm{d} \theta}\right)_{\max }$ & & $\left(\frac{d p}{d \theta}\right)_{\text {max }}$ \\
\hline $\begin{array}{l}\text { RG\% at } \\
\lambda=2.5\end{array}$ & $\begin{array}{l}\text { Timing } \\
\text { (CAD, ATDC) }\end{array}$ & $\begin{array}{l}\text { RG\% at } \\
\lambda=2.6\end{array}$ & $\begin{array}{l}\text { Timing } \\
(\mathrm{CAD}, \text { ATDC) }\end{array}$ & $\begin{array}{l}\mathrm{RG} \% \text { at } \\
\lambda=2.7\end{array}$ & $\begin{array}{l}\text { Timing } \\
\text { (CAD, ATDC) }\end{array}$ & $\begin{array}{l}\mathrm{RG} \% \text { at } \\
\lambda=2.8\end{array}$ & $\begin{array}{l}\text { Timing } \\
(\mathrm{CAD}, \text { ATDC) }\end{array}$ \\
\hline$\overline{15}$ & 13.3475 & 34 & 15.4059 & 30 & 12.1584 & 34 & 9.6236 \\
\hline 22 & 15.0894 & 38 & 15.8812 & 38 & 14.1386 & 37 & 11.1287 \\
\hline 30 & 17.3862 & 42 & 16.9109 & 45 & 14.8515 & 45 & 12.0787 \\
\hline 38 & 18.0939 & 45 & 17.703 & 52 & 15.6436 & 52 & 13.7426 \\
\hline 46 & 19.76224 & 52 & 18.4158 & 59 & 18.495 & 60 & 15.4059 \\
\hline
\end{tabular}

Table 7: Effect of RG on maximum pressure at constant relative air fuel ratio

\begin{tabular}{|c|c|c|c|c|c|c|c|}
\hline $\begin{array}{l}\text { RG\% at } \\
\lambda=2.5\end{array}$ & $\begin{array}{l}\mathrm{P}_{\max } \\
\text { In bar }\end{array}$ & $\begin{array}{l}\text { RG\% at } \\
\lambda=2.6\end{array}$ & $\begin{array}{l}\mathrm{P}_{\max } \\
\text { In bar }\end{array}$ & $\begin{array}{l}\text { RG\% at } \\
\lambda=2.7\end{array}$ & $\begin{array}{l}\mathrm{P}_{\max } \\
\text { In bar }\end{array}$ & $\begin{array}{l}\text { RG\% at } \\
\lambda=2.8\end{array}$ & $\begin{array}{l}\mathrm{P}_{\max } \\
\text { In bar }\end{array}$ \\
\hline$\overline{15}$ & 72.8985 & 34 & 74.888 & 30 & 69.8297 & 30 & 63.238 \\
\hline 22 & 75.5058 & 38 & 75.1576 & 38 & 72.5689 & 38 & 67.3999 \\
\hline 30 & 78.3729 & 42 & 75.675 & 45 & 72.4535 & 45 & 68.1964 \\
\hline 38 & 78.1336 & 45 & 75.9556 & 53 & 73.2535 & 53 & 69.4976 \\
\hline 46 & 78.5433 & 52 & 76.2255 & 59 & 74.5638 & 59 & 71.3389 \\
\hline
\end{tabular}

Higher $\lambda$ effectively reduced the maximum pressure and maximum pressure rate. The input energy in a lean mixture is lower, so a lower combustion temperature, lower maximum pressure $\left(\mathrm{P}_{\max }\right)$ and the lower maximum pressure rate $\left(\left(\frac{\mathrm{dp}}{\mathrm{d} \theta}\right)_{\max }\right)$ were expected as shown in Fig. 3. $\mathrm{P}_{\max }$ was mostly dominated by $\lambda$ rather than RG mass fractions. At very lean conditions, the influence of RG mass fraction on $\mathrm{P}_{\max }$ increased, presumably by ensuring combustion of the most dilute zones in the combustion chamber. $\left(\left(\frac{\mathrm{dp}}{\mathrm{d} \theta}\right)_{\max }\right)$ is a strong 
function of both $\lambda$ and RG mass fraction as indicated in Fig. 3.

Effect of RG mass fraction: RG addition was found to be an effective means of expanding the lean boundary of the HCCI operating window. As mentioned earlier, the operating region of $\mathrm{CNG}$ for this engine is not a practical operating window. For the knock boundary, a limit of $\left(\left(\frac{d p}{d \theta}\right)_{\max }\right)=20 \frac{b a r}{C A D}$ was chosen to represent a medium knocking condition, while in other experimental HCCI studies, $10 \frac{\mathrm{bar}}{\mathrm{CAD}}$ is usually considered as a boundary (Iida et al., 2001).

Also, the lean operating limit measured in this study is not a misfiring boundary and was defined as the maximum usable $\lambda$ without a drop in engine speed. Increasing the fuel's RG mass fraction expanded the operating window significantly on the lean side, while the pure CNG-fueled HCCI engine could operate at $\lambda \approx 2$, blending a fuel with $60 \% \mathrm{RG}$ increased the lean operation range to $\lambda \approx 3.5$. Hence, the mechanism of all the positive $\lambda$ effect on operating parameters such as decreasing maximum pressure, maximum pressure rate and is $\mathrm{NO}_{\mathrm{x}}$ (in Fig. 2) RG blending to achieve HCCI combustion without knock substantially decreased $\mathrm{NO}_{\mathrm{x}}$ emissions as indicated in Fig. 4. Note that due to the low achievable power levels, the specific $\mathrm{NO}_{\mathrm{x}}$ levels continue to be high and further combustion enhancements would be needed to make the CNGfueled HCCI engine practical. RG addition has a secondary impact on $\mathrm{NO}_{\mathrm{x}}$ emissions. Looking at any of the constant $\lambda$ lines in Fig. 4 indicates that displacing $\mathrm{CNG}$ with $\mathrm{RG}$ at a constant air/fuel ratio actually increases $\mathrm{NO}_{\mathrm{x}}$.

The observed trends of engine and combustion parameters resulting from $\mathrm{RG}$ additions in a $\mathrm{CNG}$ fueled HCCI engine can be further investigated using the cylinder pressure traces collected in this study. Figure 5 and 6 shows that RG increased the maximum cylinder pressure and maximum cylinder pressure rate substantially. With $\mathrm{NO}_{\mathrm{x}}, \lambda$ has the dominant effect. Hence, expanding the operating region towards leaner mixture can reduce $\mathrm{P}_{\max }$ and $\left(\left(\frac{\mathrm{dp}}{\mathrm{d} \theta}\right)_{\max }\right)$, while, for a given $\lambda$ increasing $\mathrm{RG}$ mass fraction increased the $\mathrm{P}_{\max }$ and $\left(\left(\frac{\mathrm{dp}}{\mathrm{d} \theta}\right)_{\max }\right)$. If we considered a reasonably acceptable noise level of $\left(\left(\frac{d p}{d \theta}\right)_{\max }\right)=10 \frac{\text { bar }}{\mathrm{CAD}}$, the only operating points would be at $\lambda=2.8$ with RG mass fraction less than $35 \%$. Also, increasing the RG mass fraction advanced $\mathrm{P}_{\max }$ and $\left(\left(\frac{d p}{d \theta}\right)_{\max }\right)$ timings earlier in the combustion cycle.

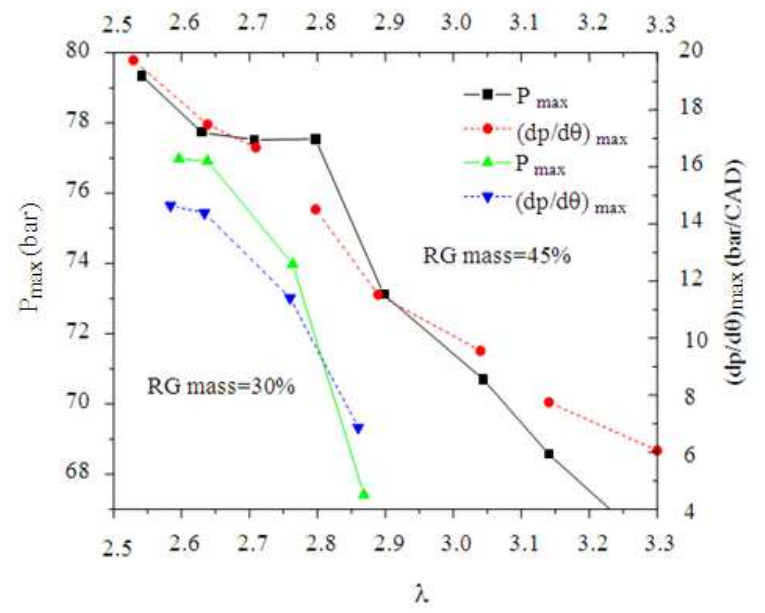

Fig. 3: Effect of relative air fuel ratio on is $\mathrm{O}_{x}$ at constant RG mass fraction lines. Effect of relative air fuel ratio of maximum pressure and maximum pressure rate at constant $R G$ mass fraction lines

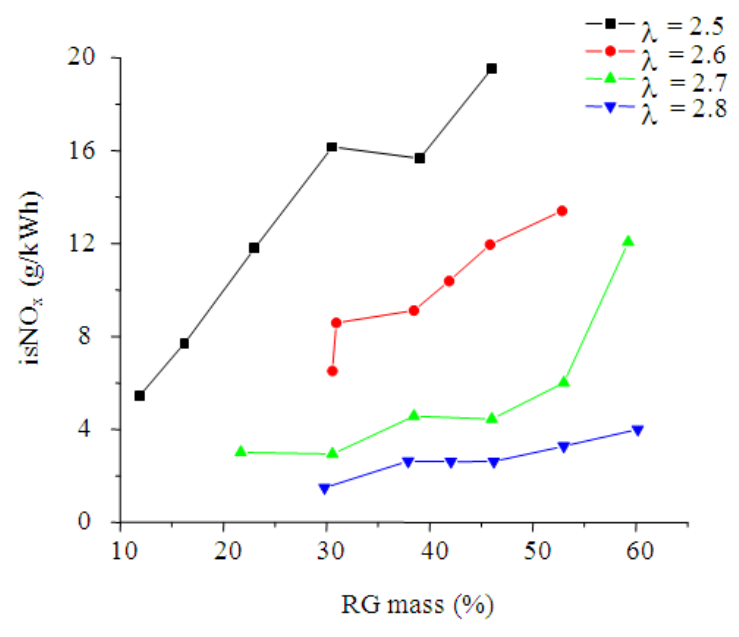

Fig. 4: is $\mathrm{NO}_{\mathrm{x}}$ increase with increasing $\mathrm{RG}$ mass fraction at constant Effect of relative air fuel ratio on is $\mathrm{NO}_{\mathrm{x}}$ at constant $\mathrm{RG}$ mass fraction lines 


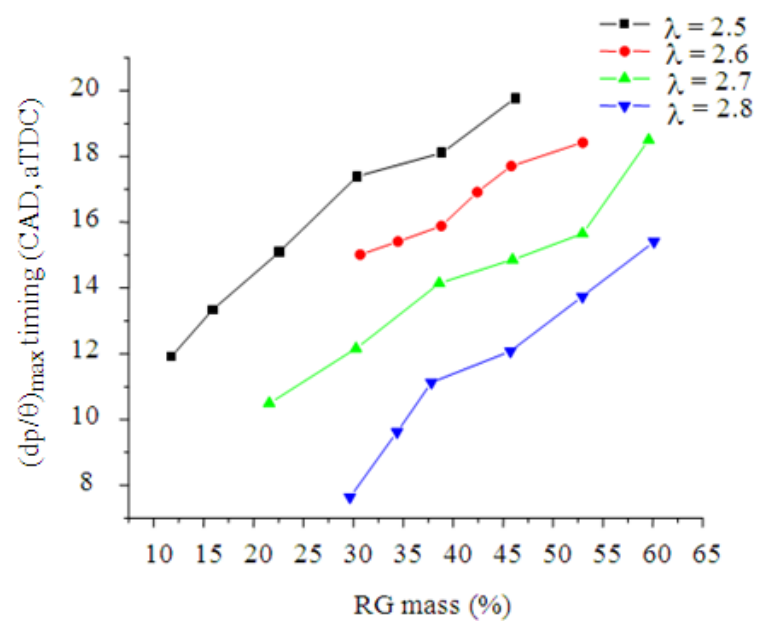

Fig. 5: Effect of RG on the maximum pressure rate at constant Effect of relative air fuel ratio on is Knox at constant RG mass fraction lines

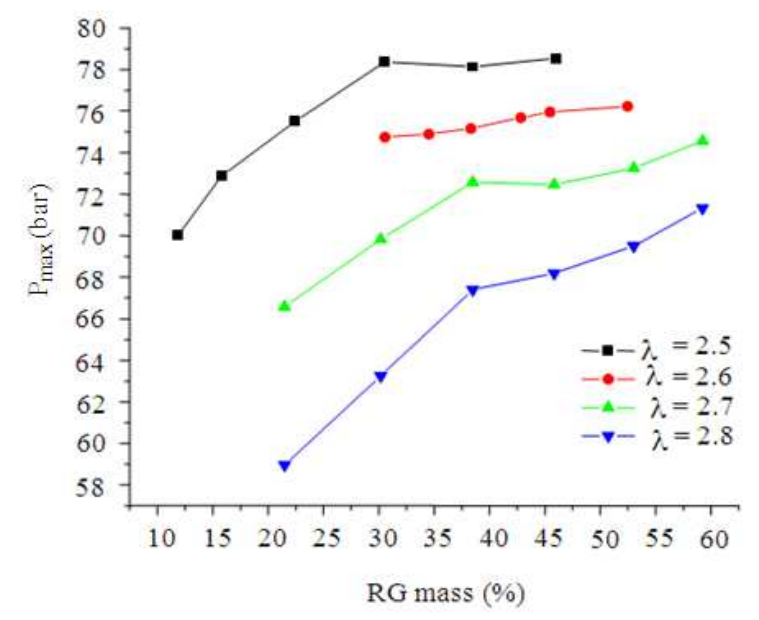

Fig. 6: Effect of RG on maximum pressure at constant Effect of relative air fuel ratio on is $\mathrm{NO}_{\mathrm{x}}$ at constant RG mass fraction lines

The effect of RG addition on combustion onset is a complicated thermal/chemical phenomenon that cannot be explained just by looking at engine operating parameters. The base fuel characteristics play an important role. For example, in another study on an HCCI engine fueled with normal heptanes (Machrafi et al., 2008) showed that increasing RG fraction actually retarded combustion timing. In that case, adding RG, which is a higher octane component than the base fuel, retarded ignition. In contrast, RG added to a CNG-fueled engine is a lower octane component than the base fuel and it advanced ignition timing. In this case, the combustion timing change could be a result of added $\mathrm{H}_{2} \mathrm{O}_{2}$ production before the main stage of methane auto-ignition.

The tendency of $R G$ to shift the allowable operating range towards leaner mixtures advances the peak pressure timing. Also, despite the elimination of audible knock, the advance in peak cylinder pressure timing generally resulted in higher peak pressures in RG addition, (Fig. 6) Overall, both the peak pressure timing and peak pressure were highly correlated with RG fraction and $\lambda$.

\section{CONCLUSION}

A CNG-fueled COMET engine was modified to operate at high compression ratios and high intake temperature enabling to attain HCCI combustion. With CNG fuel the operating range was very limited between both boundaries marked by heavy knock and misfire. The attainable engine speed range was low. Overall, the COMET engine appeared to be poorly suited for HCCI combustion with natural gas fuel. As a result, HCCI operation on pure $\mathrm{CNG}$ was considered unsuccessful because of high indicated specific $\mathrm{NO}_{\mathrm{x}}$, high cyclic variation and low efficiency. A Partial Reformar Gas replacement was found to be beneficial for expanding the operating range of fuel rich side, reducing knock severity and reducing indicated specific $\mathrm{NO}_{\mathrm{x}}$ emission, maximum peak cylinder pressure and rate of pressure rise with respect to crank angle which could not be achieved on pure CNG fueling. However, considering the situation of constant relative air fuel ratio the peak cylinder pressure, rate of pressure rise with respect to crank angle and $\mathrm{NO}_{\mathrm{x}}$ levels were increased substantially while replacing Compressed Natural Gas with Reformar Gas. This implies that the best quantity of RG is the minimum necessary to enable and enhance operation at the desirable operating point.

\section{REFERENCES}

Al-Khairi, N.N., P. Naveenchandran and A. Aziz and A. Rashid, 2011. Comparison of HCCI and SI characteristics on low load CNG-DI combustion. J. Applied Sci., 11:

Christensen, M., A. Hultqvist and B. Johansson, 1999. Demonstrating the multi fuel capability of a homogeneous charge compression ignition engine with variable compression ratio. SAE Int. DOI: 10.4271/1999-01-3679

Diaz, P.M and B.D. Prasad, 2010, Experimental investigation of compression ratio and boost pressure influence on RG blended CNG-HCCI combustion engine. Frontiers Automobile Mech. Eng. DOI: 10.1109/FAME.2010.5714813 
Haraldsson, G., P. Tunestal and B. Johansson, 2002. HCCI combustion phasing in a multi cylinder engine using variable compression ratio. SAE SAE Technical Paper. DOI: 10.4271/2002-01-2858

Heywood, J.B., 1988. Internal Combustion Engine Fundamentals. 1st Edn., McGraw-Hill, New York, ISBN-10: 007028637X, pp: 930.

Iida, M., T. Aroonsrisopon, M. Hayashi, D. Foster and J. Martin, 2001. The effect of intake air temperature, compression ratio and coolant temperature on the start of heat release in an HCCI engine. SAE International. DOI: 10.4271/2001-011880

Kaahaaina, N.B., A.J. Simon, P.A. Caton and Edwards, 2001. Use of dynamic valving to achieve residualaffected combustion. SAE International. DOI: 10.4271/2001-01-0549

Kalateh, M.R. and M. Ghazikhani, 2012. An experimental study on the effects of EGR and equivalence ratio of $\mathrm{CO}$ and soot emissions of dual fuel HCCI engine. Chem. Biol. Environ. Eng. DOI: 10.1142/9789814295048_0058
Machrafi, H., S. Cavadias and P. Gilbert, 2008. An experimental and numerical analysis of the HCCI auto-ignition process of primary reference fuels, toluene reference fuels and diesel fuel in an engine, varying the engine parameters. Fuel Process. Technol., 89: 1007-1016. DOI: 10.1016/j.fuproc.2008.03.007

Risberg, P., D. Johansson, J. Andreae, G. Kalaghati and P. Bjornbom et al., 2006. The influence of NO on the combustion phasing in an HCCI engine. SAE International. DOI: 10.4271/2006-01-0416

Sjoberg, M. and J.E. Dec, 2003, Combined effects of fuel-type and engine speed on intake temperature requirements and completeness of bulk-gas reactions for HCCI combustion. SAE International. DOI: $10.4271 / 2003-01-3173$

Warnatz, J., U. Maas and R.W. Dibble, 2006. Combustion: Physical and Chemical Fundamentals, Modeling and Simulation, Experiments, Pollutant Formation. 4th Edn., Springer Verlag, Berlin Heidelberg New York, ISBN-10: 3540259929, pp: 378. 